Brand, N., Beens, B., Vuuregge, E., Batenburg, R. Engineering governance: introducing a governance meta framework. International Journal of Corporate Governance: 2011, 2(2), 106-118

\begin{tabular}{|l|l|}
\hline Postprint Version & 1.0 \\
\hline Journal website & http://www.ingentaconnect.com/content/ind/ijcg/2011/00000002/00000002/art0 \\
& 0002 \\
\hline Pubmed link & $10.1504 /$ IJCG.2011.041150 \\
\hline DOI
\end{tabular}

This is a NIVEL certified Post Print, more info at http://www.nivel.eu

\title{
Engineering governance: introducing a governance meta framework
}

\author{
N. BRAND ${ }^{* 1}$, B. BeEns ${ }^{2}$, E. VUUREGGE ${ }^{3}$, R. BATENBURG ${ }^{4}$ \\ ${ }^{1}$ Institute of Information and Computing Sciences, Utrecht University, and Hora Est Company, Lupine-oord \\ 63, 3991VH Houten, the Netherlands E-mail: nicobrand@planet.nl ${ }^{*}$ Corresponding author \\ ${ }^{2}$ Atos Consulting, Utrecht, Papendorpseweg 93, 3528 BJ Utrecht, the Netherlands E-mail: \\ ben.beens@atosorigin.com \\ ${ }^{3}$ Vuuregge Consulting, Utrecht, De Hoef 3H, 5311 GH Gameren, the Netherlands E-mail: \\ erik@erikvuuregge.nl \\ ${ }^{4}$ Department of Information and Computing Sciences, Institute of Information and Computing Sciences, \\ Utrecht University, Padualaan 14, De Uithof, 3584CH Utrecht, the Netherlands E-mail: ronald@cs.uu.nl
}

\begin{abstract}
There is a need for a framework that depicts strategic choices within an organisation with regard to potential governance structures. The governance meta framework provides the necessary structure in the current developments of governance. Performance as well as conformance are embedded in this framework and provide the balance for all governance domains.
\end{abstract}

Reference to this paper should be made as follows: Brand, N., Beens, B., Vuuregge, E. and Batenburg, R. (2011) 'Engineering governance: introducing a governance meta framework', Int. J. Corporate Governance, Vol. 2, No. 2, pp.106-118.

Biographical notes: N. Brand obtained his Master's in Business and Informatics from Radboud University Nijmegen and his Master's in Management Consultancy at the Post Graduate Education of the Vrije University Amsterdam. He is the owner of Hora Est Company and a Research Fellow at University Utrecht. Previously, he worked as a Senior Manager within Ernst \& Young and Capgemini. His research focuses on governance engineering, business-IT alignment, sustainability and creativity. He is the author of several publications and he lectures at different universities.

Ben Beens received his Bachelor of ICT from Hanzehogeschool Groningen and obtained his Master of Business Informatics from Utrecht University. He started at Atos Consulting as an Information Risk Management Consultant.

During one of his projects, he designed and developed a role based access control application for ING. As of 2010, he is the Security Officer at Ciber (Netherlands). His research interests are in the field of information risk management, business IT alignment, governance and role based access control.

Erik Vuuregge received his Bachelor of Software Engineering from Avans Hogeschool and obtained his Master of Business Informatics in 2007 from Utrecht University. In 2007, he developed an online performance management tool for a successful recruitment company. After his Master, he founded Iblux - Business/IT Services at the beginning of 2008 to serve businesses with solutions in the areas of business IT alignment, (internet) development and 
search engine optimisation. Since 2010, his company is located in Zaltbommel, The Netherlands. His research interests are in the field of business IT alignment, IT governance, IT strategy and internet development.

Ronald Batenburg obtained his Masters from Utrecht University and his PhD in 1991 at Groningen University. After his PhD, he worked at the Universities of Utrecht, Tilburg and Nijmegen as an Assistant Professor in Organisation Science, Strategic Policy Making and HRM. Since 2000, he is an Associate Professor at Utrecht University, Department of Information and Computing Sciences. As of 2009, he also works as a Programme Coordinator at the Netherlands Institute for Health Services Research (NIVEL). His research interests and publications are in the field of business IT alignment, healthcare organisation and manpower planning.

\section{INTRODUCTION}

In the early years of the 20th century the world was shocked by the announcements of the book keeping scandals of Enron, WorldCom, Ahold and other prominent enterprises.

After the discovery of these scandals, the president of the USA, George Bush, urged for a law to protect the nation from corporate corruption, bring back the confidence of investors and the conscience of the nation. Therefore on 30 July 2002 he signed the Sarbanes-Oxley Act (SOX) (Sarbanes-Oxley, 2002). This forcing legislation was mainly focusing on risk management and financial reporting.

These scandals, the differences between legal systems around the world and the internationalisation of businesses, have increased the attention to corporate governance (Cools, 2006). With a well defined corporate governance structure a company can gain added value with the needed assurance. In addition, badly governed enterprises have lower profit margins and are more cyclical than well governed enterprises (Philippon, 2006).

'Good' governance is not restricted to corporate governance. In terms of integrated internal and external stakeholder management and control, governance has become a topic in various business domains, including IT. For instance, Weill defined the most common governance decision structures related to IT within an organisation (Weill and Ross, 2004). The frameworks of the IT governance Institute (Cobit, Val IT) define IT governance processes and control objectives.

In general, governance is about organisations in control of their business activities.

But what is the best way to get the evidence for control, how to organise responsibilities and how to get the guarantees? What is the best way to ensure that the governance structure defined by the board is understood by the business? In terms of compliance or conformance activities most attention is going to corporate governance and IT governance. Less emphasis is on the value creation and performance aspect of governance.

Corporate governance deals with transparent governance towards stakeholders as it is important for the top management to have separate ownership and control inside the organisation. Since the emerging and strategic importance of IT (Venkatraman et al., 1993), IT governance itself supports the corporate governance activities and ensures board and CEO of transparent and responsible IT. The notion that corporate governance and IT governance focus on the compliance or conformance activities and less on the value creation or performance, is noted by several authors, e.g., compliance and performance cannot be seen as independent activities. They are linked as if they are two essentially different ends of the same continuum, rather than dimensions operating on independent organisational plane (Bhimani and Soonawalla, 2005). Also the Charted Institute of Management Accountants (CIMA) and the International Federation of Accountants (IFAC) claim that it is important to have a balance between conformance and performance (CIMA, 2003; IFAC, 2004).

Currently, the problem within organisations emerges that corporate governance and IT governance structures have been developed parallel to each other. In addition, governance structures are often too generic to be applied for every organisation.

Therefore, there is a need for a framework that depicts strategic choices within an organisation with regard to potential governance structures. To make this possible, it is also needed to define an integral framework for governance. This is the main goal of this paper. 
In this paper corporate and IT governance are conceptually brought together, and integrated with the new terms of business and enterprise governance. We introduce this as the governance meta framework. This framework approaches performance and conformance differently and points out the importance of the business aspect in the governance domain.

The framework enables companies to overview the different governance domains and apply an integrated approach to conformance and performance.

In the following section the theoretical background is provided on corporate governance and the relation with other governance domains is described. This followed by an introduction to business governance. This section will explain how business governance is needed in the domain and which connection the business governance has with corporate and IT governance. In Section 4 the framework is constructed and presented. Section 5 closes this paper with the conclusion and provides suggestions for further research.

\section{CORPORATE AND IT GOVERNANCE}

\subsection{Corporate governance}

To solve the agency problem between the CEO of a corporation and multiple principles like shareholders, creditors, suppliers, clients and other parties; corporate governance emerged. Due to several occurrences, rules and regulations corporate governance has changed to its current state. With the help of frameworks such as Enterprise risk management (ERM) from COSO, it is possible for the board of directors to minimise risk and maximise the return on investment for the shareholders. Transparency and responsibility are the two main focus areas of corporate governance. In other words, corporate governance can be described as: 'the separation of ownership and control' (Brand and Boonen, 2007; Tirole, 2001). The concept corporate governance is already known for centuries. It originates from 1602 when the Dutch 'Verenigde Oost-indische Compagnie' (VOC) was established. The VOC is considered one of the world's first corporations quoted on the stock exchange. With the introduction of stock, management and financing where separated. This separation introduced the agency problem. An agent or CEO of a corporation performing activities on behalf of principles like shareholders, creditors, suppliers, clients and other parties (Walsh and Seward, 1990). The agency problem is the distortion of the agency relationship when there is incomplete or asymmetric distribution of information between the agent and the principles (Becht et al., 2005).

In the contrary to all other stakeholders like the banks, suppliers and employees, the stockholders, have no assurance of getting a return on investment (Shleifer and Vishny, 1997). According to economics, monitoring, internal discipline mechanisms, external discipline mechanisms, laws and regulations, and an active merger market should lead directors to get the best possible return on investment for stockholders (Coase, 1992; Williamson, 2005). To ensure that companies meet certain levels of trust, laws and regulations are necessary to enforce the transparency of a corporation. The Sarbanes-Oxley law is such an initiative to bring back the confidence of the investor (Sarbanes-Oxley, 2002).

To ensure that organisations comply to these standards, they should do internal control, have independent external accountants and have a monitoring authority that can enforce compliance. Organisations use several tools, frameworks and applications to become in control. One of the frameworks is the ERM framework from the committee of sponsoring organisations of the Treadway Commission (COSO). The American Public Company Accounting Oversight Board advises to use the ERM framework of COSO to get compliant with SOX (PCAOB, 2002). "COSO was developed and accepted as the guidelines of best practices for SOX Section 404 (risks of financial reporting) and as new integrated ERM framework” (Drew et al., 2006). ERM is interrelated with corporate governance by providing information to the board of directors of the most significant risks and how they are being managed and it interrelates with performance management by providing risk-adjusted measures, and with internal control, which is an integral part of ERM (COSO, 2004a).

In this paper we will use the definition of corporate governance as follows. Corporate governance is the system by which business corporations are directed and controlled. The corporate governance structure specifies the distribution of rights and responsibilities among different participants in the corporation, such as the board, managers, shareholders and other stakeholders, and spells out the rules and procedures for making decisions on corporate affairs. By doing this, it also provides the structure through which the company objectives are set, and the means of attaining those objectives and monitoring performance (OECD, 2004). 


\subsection{IT governance}

IT as a strategic asset gets growing attention in corporations to help with new laws, like Sarbanes-Oxley (ITGI, 2006b). With IT and IS it is possible to meet financial reporting demands in a timely way and enhance transparency and integrity (ITGI, 2006a). While corporate governance developments have primarily been driven by the need for transparency of enterprise risks and the protection of shareholder value, the pervasive use of technology has created a critical dependency on IT that calls for a specific focus (ITGI, 2003). It is important to supply a clear insight and advice on the IT strategy, because of the contribution towards the improvement of internal control supporting the corporate governance objectives (Posthumusa and von Solms, 2005). This is supported by Weill who claims that a good governing of IT, we can learn from good financial reporting and corporate governance (Weill and Ross, 2004). Another trigger for IT governance is the increasing and significant impact of IT on the success of the enterprise. These resources should be directed and controlled on corporate level, and thus actually governed. The corporate governance approach can be used for IT governance that deals with the alignment of enterprise objectives, IT planning, IT strategy, and more aspects of how IT is directed and controlled.

In their book 'IT governance' Weill and Ross describe the linking of strategy, IT governance and performance. Unforeseen market changes causes enterprises to re-think their business strategy. Enterprises want the agility to restructure business based on the market changes. Major shifts in strategy would force a change in organisational structure that is in most cases designed to achieve a particular strategy. By overcoming the limitations of organisational structure, governance can enable greater agility in enterprises. Thus effective IT governance will become increasingly important as the pace of changes accelerates.

According to Van Grembergen (2003), the unclear difference between IT governance and IT management can be explained as a difference between the long and short term, and as a difference between internal and external focus. IT management is more focused on the intern organisation and the short term. IT governance is than focuses on the long term and externally driven.

Weill and Ross sees the difference between management and governance as the difference between a soccer team running faster and practicing longer and the coaches stepping back to analyse its composition and game strategy (Weill and Ross, 2004). IT management is than focused on the internal effective supply of IT services and products and the management of present IT operations. IT governance in its turn is much broader, and concentrates on performing and transforming IT to meet present and future demands of the business (internal focus) and the business' customers (external focus).

According to Weill is effective IT governance the single most important predictor of getting value from IT (Weill and Woodham, 2002). IT governance has to provide the organisational structures and to enable the creation of added business value through IT, the assurance that there are no bad IT investments and that there are adequate IT control mechanisms (Van Grembergen, 2000).

To follow the corporate governance strategy and objectives there are several frameworks and standards available for the support of those objectives with IT.

Following the ERM framework from COSO, COBIT was then developed for the control of the IT environment (Brand and Spits, 2005; COSO, 2004a, 2005; ITGI, 2005).

COBIT stands for Control Objectives for Information and related Technology. COBIT and COSO have a close relationship (ITGI, 2006a). Where COSO is more focused on corporate governance, COBIT is focused on IT governance. COBIT provides an IT governance instrument that allows managers to overcome the gap with respect to control requirements, information systems and information technology issues and business risk, and in order to communicate that level of control to the stakeholders. If an organisation uses the COSO framework for corporate governance, COBIT can help to implement the strategy on IT. Next to that, it is possible with COBIT to created added value with the implementation of an IT strategy. It is possible to use other frameworks and models to practice good IT governance. It does not matter in fact which framework is used, the most important issue is that it is necessary to have attention for the governance of IT and to do that it in a consistent homogenous way. Val IT is lately introduced as an IT governance framework focusing on the governance of IT enabled investments. In this research IT governance is defined as:

"IT governance is the system in which IT within enterprises is directed and controlled. The IT governance structure specifies the distribution of rights and responsibilities among different participants, such as the board, business and IT Managers, and spells out the rules and procedures for making decisions on IT. 
Brand, N., Beens, B., Vuuregge, E., Batenburg, R. Engineering governance: introducing a governance meta framework. International Journal of Corporate Governance: 2011, 2(2), 106-118

By doing this, it also provides the structure through which the IT objectives are set, and the means of attaining those objectives and monitoring performance." (Brand and Boonen, 2007) referencing OECD

\section{BUSINESS GOVERNANCE}

Doing business can be defined as, an organisation engaged in producing goods or services and to make a profit (Kariger and Fierro, 2007). Along the value chain there is creation of value (added value) what makes it possible for an organisation to make a profit (Peppard and Ward, 2002). The improvement and/or alignment of this value chain will increase the performance of the organisation (Kaplan and Norton, 2006; Porter, 1985). Still, an organisation is subordinate to legislation and has to deal with other aspects as social, environmental and political demands. As conformance is important for organisations and performance is embedded in doing business, conformance and performance should be part of the direction and control of business, in other words: Business governance.

In most cases alignment of business and IT is the driver for IT governance initiatives.

This research uses this driver of business IT/alignment as one of the motives for introducing business governance. There is a strong awareness of business/IT alignment (Kaplan and Norton, 2006; Luftman and Kempaiah, 2007; Scheper, 2002). Where IT supports the business activities and business should be aligned with IT to increase performance. In their paper continuous strategic alignment of Venkatraman, Henderson and Oldach, write that IT governance is the selection and use of mechanisms for obtaining the required IT competences what is an analogous to business governance which involves 'make-versus-buy' choices in business strategy (Venkatraman et al., 1993). They also explain that top management is responsible for the impact of business strategy of changing IT governance patterns. The COBIT model also prescribes that IT should be aligned with business and should follow the corporate strategy (ITGI, 2005).

There are authors that mention business governance in their papers or books, but are not elaborate or detailed on this topic (Brand and Boonen, 2007; CIMA, 2003). CIMA describes corporate governance as the conformance dimension and Business governance as the performance dimension of enterprise governance. Performance is the creation of value along the value chain. CIMA claims that the opposite of conformance is performance as an organisation needs to provide added value for its shareholders. Still, conformance can also lead to value creation while performance can lead to assurance (CIMA, 2003). The notion of CIMA that there should be a performance and conformance side to governance is supported by other authors. The IFAC believes that the enterprise governance framework provides a timely reminder to organisations to balance conformance requirements with the need to deliver long term strategic success through performance (IFAC, 2004). As Bhimani writes in his paper: "it is necessary for corporations to accept the notion of corporate performance and conformance” (Bhimani and Soonawalla, 2005). Conformance and performance will contribute to the alignment of business and IT (Drew et al., 2006; Luftman, 2000; Van Grembergen and De Haes, 2005; Venkatraman et al., 1993). Bhimani claims that performance and conformance as combination are necessary to create added value and further research is important (Bhimani and Soonawalla, 2005; Westra, 2005).

Based upon definitions of other writers (Brand and Boonen, 2007; Luftman, 2000; OECD, 2004) we define business governance as follows:

"Business governance is the system by which business activities within enterprises are directed and controlled. The Business governance structure specifies the distribution of rights and responsibilities among different participants, such as the board, IT and business managers, and spells out the rules and procedures for making decisions on business activities. By doing this, it also provides the structure through which the business objectives are set, and the means of attaining those objectives and monitoring performance."

\section{GOVERNANCE META FRAMEWORK}

\subsection{Conformance and performance}

Looking at the model of CIMA there are two deficiencies. First, there is no notion of IT governance although CIMA claims IT governance is a part of corporate governance. The idea that IT governance only supports corporate governance is in our opinion not correct.

For example, business activities are supported by IT in case of the implementations of controls. This can mean that Business governance can also be supported by IT governance. In addition, CIMA claims that 
conformance can create added value. COSO helps management achieve entity's performance and profitability targets and prevents loss of resources (COSO, 2004b). Also, IT governance initiatives that include adoption of control frameworks and best practices to help monitor and improve critical IT activities, increase the business value and reduce business risks (ITGI, 2005). This implies that IT governance should also be part of a model like that of CIMA.

The second deficiency of the CIMA model comes up when looking at the distinction made between corporate, business and IT governance. The COSO ERM framework as well as COBIT addresses a performance and conformance side of the framework. With this and the CIMA model in mind, it is possible to say that every domain of governance deals with conformance and performance. The past few years the focus has been on compliance because of the strong attention on scandals and finance, but performance is present in these frameworks and all domains of governance.

With this reasoning we construct a new governance meta framework. This framework should contain corporate, business, and IT governance. The model from CIMA has corporate and business governance as a part of enterprise governance. In the governance meta framework, enterprise governance will be the container covering all governance activities in an organisation. Corporate governance is placed on top as most organisations start with the implementation of corporate governance. Starting from here the strategy and objectives are determined and executed by the business and supported by IT. Still the model does not cover the performance and conformance attributes. According to Luftman, doing business is not just focusing on conformance but also the achievement of business objectives, so the performance dimension. Conformance and performance are equalities but also opposites and are necessary for the balance in the governance meta framework (see Figure 1).

\section{[FIGURE 1]}

Our governance meta framework contains enterprise, corporate, business, and IT governance with a performance and conformance side. The separation is done to indicate the importance of both areas and the tension between them. Tension could create risks and according to fundamentals of corporate governance, risks should be controlled.

The governance meta frame should provide a starting point for an integral approach for governance. With the current changes on the market SOX compliant companies are looking for new ways to get back the investments that they have made. This governance meta framework is the starting point for the conformance and performance approach.

\subsection{Application of the governance meta framework}

The governance meta framework encompasses the major governance frameworks. These frameworks are more general applied, without considering the specific situation within the organisation. Based upon the strategy or the specific situation of the organisation, the governance meta framework will fulfil the governance processes needed. Examples of such situations are compliance orientation, innovation orientation, service orientation, etc. But also the industry and product life cycle (Ward, 2002) influences the chosen and number of governance processes. The more mature an organisation is, the more governance processes are suitable and applied. Based upon best practices and theoretical guidance the framework will grow more mature.

Creating an alignment between corporate, business, and IT governance is a goal that is important for organisations. Alignment is also important for the performance and conformance dimension. With the alignment of governance (Venkatraman et al., 1993) strategic alignment can be pursued what can result in added value. The notion for business IT/alignment starts with the book from Scott Morton on the corporation of the 1990s (Scott-Morton and Michael, 1991). With scholars and organisations like ITGI, Kaplan, Venkatraman and Scheper writing about business/IT alignment, business governance is one of the topics that should be further investigated and used as an incentive to build a model that will have the possibility for measuring alignment embedded in the Governance Meta Framework. The BITA model from Scheper is a model that makes it possible to measure alignment. Scheper defines five dimensions, based on Scott Mortons research, that are of crucial importance for an organisation. The dimensions are strategy and policy, organisation and processes, monitoring and control, people and culture, and information technology. The hypothesis of Scheper is that alignment of the five business dimensions will significantly contribute to the performance of an organisation. Others have successfully adapted this model to their field of interest (Batenburg and Versendaal, 2006). 
In the research, BITA was used for the alignment of the different governance domains and sub dividing of core processes. Alignment is in most cases measured with maturity levels that are later on important to measure the effectiveness of the processes. This is not done in this research but can be important for future research. SEI at Carnegie Mellon University developed the capability maturity model to support the building of improvement plans in all kind of areas (CMMI, 2006). With the intention to measure the maturity of companies on the governance domains, it is important to think of ways how this can be done. A capability level consists of a generic goal. This generic goal is related with practices and process areas, which can improve the organisation's processes associated with that process area. The maturity levels are more focused on processes. As you satisfy the generic goal set by generic practices at each capability level, you reap the benefits of process improvement for that process area embedded in the maturity levels.

\section{CONCLUSIONS}

This research started with the introduction explaining the attention for corporate governance. An emerging side effect is that IT governance showed up on the agenda of the CIO. IT systems automate portions of the financial processes and should be governed.

Different authors described the continuous process of alignment between business and IT.

Good governance has a positive influence on the value of the corporation. However this issue has not been investigated towards the relationship between business conformance (broader sense of compliance) and business performance. This research considers this as business governance. Control of performance can be achieved by the planning and budgeting process, with reliable information, which is on the other hand essential for good corporate governance. Objective for this research was to show business governance as a middle layer between corporate governance and IT governance and how they are related to each other.

Based on the knowledge about the different governance domains, we constructed a governance meta framework. Corporate governance is defined as the way a corporation is directed and controlled and deals with the rules of the game that are mandatory by law.

An ERM framework can be used to mitigate risk about corporate affairs. However, doing business is not just focusing on conformance but also the achievement of business objectives. This research defines this as the performance dimension of business governance. To achieve business objectives it is important to invest in governance to achieve maximum benefits. Same holds for investing in IT as critical to get maximum benefit. Our governance meta framework can be the starting point for organisations and scholars to have a good reference point as where frameworks like COSO, COBIT and ValIT can be placed and where a future business governance Framework should be placed and integrated.

Every domain from corporate, business or IT governance deals with conformance as well as performance. However, because of past events, the focus of corporate governance and IT governance has been on compliance. With current developments and the pressure to create added value for stakeholders, the attention for performance as well as conformance has increased. Business governance needs to be one of the topics of Enterprise governance next to corporate and IT governance. The governance meta framework is a helpful model that can be used to discuss the topics corporate, business, and IT governance. In overall, this research provides an insights and a Meta model for future business governance research. One thing is clear, business governance needs much more attention.

\subsection{Limitations}

As in every research, a number of limitations can be listed on issues that have limited the research in different ways. The concept of governance is enormous and many authors have published many papers on this subject with different perspectives. Also many professionals have created many visions on how the governance of an enterprise should be done to achieve maximum benefits.

Another limitation is the scandals and other events as witnessed with Ahold and WorldCom, and that have made it a sensitive topic to talk about. Because it is about laws and regulations, certain statements cannot be made by respondents, who were used to validate the work. This, because wrong interpretation of words, can have serious consequences when coming out in the media. This could have a negative outcome for the trust and financial position of a company. It is even possible that it will have legal consequences. This had an impact on the way the research could be done. 


\subsection{Future research}

The topic of business governance can be extended, be subjected to additional validation, used to go more in-depth, or combined with new theories. Additional research and validation could increase the attention for the Governance Meta Framework and Business governance. Additional quantitative and qualitative research is important for a further scientific foundation of business governance. With scholars and organisations like ITGI, Kaplan and Venkatraman writing about business/IT alignment, and with a high awareness of IT governance, the governance meta framework is the start of structuring the design process for governance. Since the governance meta framework is drawn up out of corporate, business and IT governance, one can notice that not all the domains have been elaborated at the same level.

Business governance is one of the topics that should be further investigated and used as an incentive to build a model that will have the possibility for measuring alignment embedded in business governance. Alignment between corporate, business, and IT governance is a goal that is vital important for organisations. Alignment is also important for the performance and conformance dimension. The ultimate goal for business governance would be there to find out how business governance conformance and performance are influencing each other in terms of added value for a company.

In other governance domains then Business governance, there are different tools and Frameworks available such as, for example frameworks like COSO, COBIT and ValIT.

A topic for further research is a Business governance Framework that has a close relation with COSO and COBIT. This close relation is important because of two reasons. First reason, COSO is a framework that is advised by the American Public Company Accounting Oversight Board in combination with SarbanesOxley. Second reason, COBIT is closely related to COSO and is a framework that is often used by companies for IT governance activities (ITGI, 2006b). When the Business governance Framework is developed it could benefit from these two frameworks.

A potential business governance Framework needs a set of processes that can be used by a manager to become compliant with rules and regulation in such a way that it is accountable and according the principles of corporate governance. In the same way as COSO is being used by many corporations as ERM framework for corporate governance and COBIT is used for IT governance, the processes of business governance should be usable in the same way.

\section{REFERENCES}

Batenburg R.S. and Versendaal J. (2006) 'Alignment matters - improving business functions using the procurement alignment framework', Paper presented at the Workshop Inkoop Onderzoek Nederland (WION).

Becht, M., Bolton, P., Zalaznick, B., Zalaznick, D. and Röell, A. (2005) Corporate Governance and Control, European Corporate Governance Institute.

Bhimani, A. and Soonawalla, K. (2005) 'From conformance to performance: the corporate responsibilities continuum', Journal of Accounting and Public Policy, Vol. 24, No. 3, pp.165-174.

Brand, K. and Boonen, H. (2007) IT Governance based on Cobit 4.0 - A Management Guide, 2nd ed., 1st impression ed., (English), Van Haren Publishing.

Brand, N. and Spits, F. (2005) 'Compliance met behulp van COSO en cobit', Facetoface, (in Dutch), Vol. 3 , No. 1, pp.18-20.

CIMA (2003) Enterprise Governance - A CIMA Discussion Paper, The Chartered Institute of Management Accountants.

CMMi (2006) 'CMMi for development', Pitssburg, Carnegie Mellon Software Engineering Institute.

Coase, R. (1992) 'The institutional structure of production', The American Economic Review, Vol. 82, No. 4, pp.713-719.

Cools, K. (2006) 'Controle is goed, vertrouwen is beter (over bestuurders en corporate governance)', 2e druk ed., (in Dutch), Stichting Management Studies (SMS), Den Haag.

COSO (2004a) Enterprise Risk Management - Integrated Framework - Framework (Framework), The Committee of Sponsoring Organizations of the Treadway Commission, Jersey City.

COSO (2004b) Enterprise Risk Management - Integrated Framework Executive Summary.

COSO (2005) Internal Control over Financial Reporting - Guidance for Smaller Public Companies

Executive Summary.

Drew, S.A., Kelley, P.C. and Kendrick, T. (2006) 'CLASS: five elements of corporate governance to manage strategic risk', Business Horizons, Vol. 49, No. 2, pp.127-138. 
IFAC, P.A.i.B.C.P.o. (2004) Enterprise Governance: Getting the Balance Right, IFAC, New York.

ITGI (2003) Board Briefing on IT Governance, 2nd ed., The IT Governance Institute, Rolling Meadows.

ITGI (2005) Cobit 4.0., IT Governance Institute, Rolling Meadows.

ITGI (2006a) The Control Objectives for Sarbanes-Oxley, available at http://www.itgi.org.

ITGI (2006b) IT Governance Global Status Report-2006, IT Governance Institute, Rolling Meadows.

Kaplan, R.S. and Norton, D.P. (2006) Alignment - Using the Balanced Scorecard to Create Corporate

Synergies, Harvard Business School Publishing Corporation, Boston.

Kariger, B. and Fierro, D. (2007) Dictionary.com, available at http://dictionary.reference.com/ (accessed on 02-03, 2007).

Luftman, J. (2000) 'Assessing business-IT alignment maturity', Communications of the Association for Information Systems, Vol. 4, No. 14, pp.1-51.

Luftman, J. and Kempaiah, R. (2007) 'An update on business-IT alignment: a line has been drawn', MIS Quarterly Executive, Vol. 3, No. 6, pp.165-177.

OECD (2004) OECD Principles of Corporate Governance, (English), OECD Organisation for Economic Cooperation and Development, Paris.

PCAOB (2002) PCAOB - Public Company Accounting Oversight Board, available at http://www.pcaobus.org/ (accessed on 06-19, 2007).

Peppard, J. and Ward, J. (2002) Strategic Planning for Information Systems, 3rd ed., John Wiley \& Sons, Ltd., Cranfield Philippon, T. (2006) 'Corporate governance over the business cycle', Journal of Economic Dynamics and Control, Vol. 30, No. 11, pp.2117-2141.

Porter, M.E. (1985) Competitive Advantage, Free Press, New York.

Posthumusa, S. and von Solms, R. (2005) 'IT oversight: an important function of corporate governance', Computer Fraud and Security, Vol. 6, pp.11-17.

Sarbanes Oxley (2002) Public Law 107-204, 107-204 C.F.R.

Scheper, D.W.J. (2002) Business IT Alignment: Oplossing voor de Productiviteitsparadox, (in Dutch), Universiteit van Utrecht, Utrecht.

Scott-Morton, S. and Michael, S. (1991) The Corporations of the 1990s: Information, Technology and Organizational Transformation, Oxford University Press, New York, US.

Shleifer, A. and Vishny, R.W. (1997) 'A survey of corporate governance', Journal of Finance, Vol. 52, No. 2, pp.737-783.

Tirole, J. (2001) 'Corporate governance', Econometrica, Vol. 69, No. 1, pp.1-35.

Van Grembergen, W. (2000) 'The balanced scorecard and IT governance', Information Systems Control Journal, Vol. 2, pp.40-43.

Van Grembergen, W. (2003) Strategies for Information Technology Governance, IGI Global Van Grembergen, W. and De Haes, S. (2005) 'IT governance structures, processes and relational mechanisms: achieving IT/business alignment in a major Belgian financial group', System Sciences, HICSS'05, Proceedings of the 38th Annual Hawaii International Conference, pp.1-10.

Venkatraman, N., Henderson, J.C. and Oldach, S. (1993) 'Continuous strategic alignment: exploiting information technology capabilities for competitive success', European Management Journal, Vol. 11, No. 2, pp.139-149.

Walsh, J.P. and Seward, J.K. (1990) 'On the efficiency of internal and external corporate control mechanisms', Academy of Management Review, Vol. 15, No. 3, pp.421-458.

Ward, J.P. and John, L. (2002) Strategic Planning for Information Systems, 3rd ed., Wiley Series.

Weill, P. and Ross, J.W. (2004) IT Governance, Massachusetts.

Weill, P. and Woodham, R. (2002) Don't Just Lead, Govern: Implementing Effective IT Governance, (electronic version), pp.1-17, available at http://ssrn.com/paper=317319 (accessed on 06-20-2007).

Westra, S. (2005) Corporate Performance en Corporate Governance Bijten Elkaar Niet, Finance \& Control - Organisatie en Processen, (in Dutch), pp.52-55.

Williamson, O.E. (2005) 'The economics of governance', American Economic Review, Vol. 95, No. 2, pp.118. 
Brand, N., Beens, B., Vuuregge, E., Batenburg, R. Engineering governance: introducing a governance meta framework. International Journal of Corporate Governance: 2011, 2(2), 106-118

Figure 1 Governance meta framework with conformance and performance (see online version for colours)

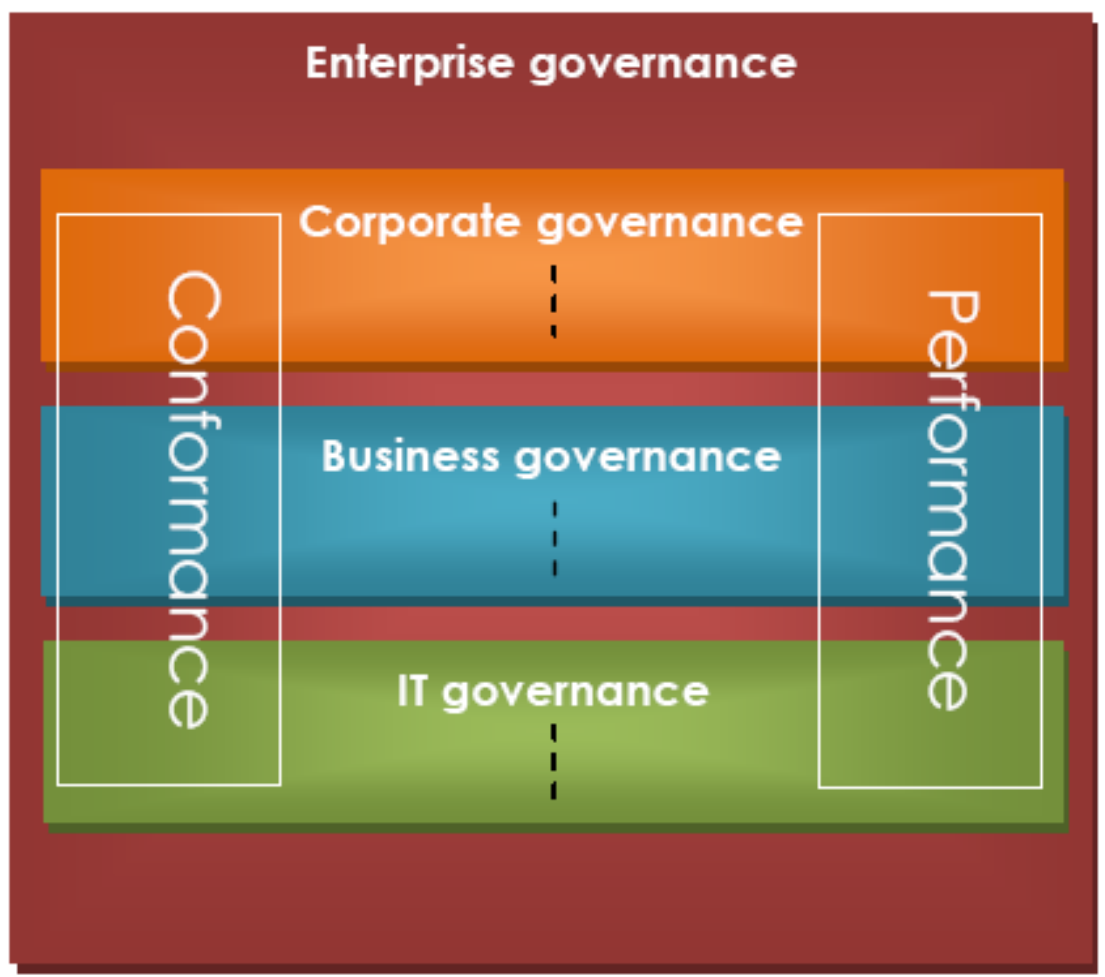

